\title{
A GLYCOGEN-RICH SEGMENT OF THE TUBULI RECTI AND PROXIMAL PORTION OF THE RETE TESTIS IN THE GUINEA-PIG
}

\author{
D. W. FAWCETT AND M. DYM \\ Laboratory of Human Reproduction and Reproductive Biology, and \\ Department of Anatomy, Harvard Medical School, Boston, \\ Massachusetts 02115, U.S.A.
}

(Received 21st August 1973)

\begin{abstract}
Summary. The epithelium lining a distal segment of the tubuli recti and neighbouring portions of the rete testis in the guinea-pig has been found to store large amounts of glycogen. The cell bodies are distended by a large central deposit of glycogen that displaces the nucleus far into the apex and reduces the cytoplasm to a thin peripheral layer adjacent to the cell membrane. Glycogen storage by these cells seems to have been overlooked until now because they break open and lose their content during routine histological preparation. Success in preserving and staining their glycogen is attributed to use of ferrocyanide-reduced osmium tetroxide after primary glutaraldehyde fixation.
\end{abstract}

\section{INTRODUCTION}

Interest in the exocrine secretion of the testis has been stimulated by success in collection of fluid by cannulation of the rete testis of the ram (Voglmayr, Waites \& Setchell, 1966) and of the rat (Tuck, Waites, Young \& Setchell, 1970). It is now believed that the fluid in which spermatozoa are transported to the ductuli efferentes and ductus epididymidis is a mixture of two secretions of differing composition-one being secreted in the seminiferous tubules and the other in the tubuli recti or rete testis (Setchell \& Waites, 1971). The structure of the seminiferous tubules has been studied in considerable detail at both the light and electron microscope levels (Dym \& Fawcett, 1970; Dym, 1973; Fawcett, 1974), but morphological studies of the tubuli recti and rete testis have been relatively few (Roosen-Runge, 1961; Leeson, 1962; Dym, 1974).

The general features of the excurrent duct system of the guinea-pig testis were described in a classical comparative study by Benoit (1926). A labyrinthine system of interconnecting channels was found at the vascular pole of the testis, the system extending a considerable distance into the interior of the gonad. This species was therefore categorized as having an 'axial rete' in contrast to the 'superficial rete' of the rat. The ultrastructure of the guinea-pig rete was first examined by Ladman \& Young (1958) at a time when methods of tissue preservation for electron microscopy were still relatively primitive. 
Only the flat or low cuboidal epithelium of the distal portion of the rete appears to have been sampled. Perey, Clermont \& Leblond (1961) examined the junctional region of the seminiferous tubules with rete testis in the rat. They identified an 'intermediate region' where the diameter of the seminiferous tubule rapidly diminished and the epithelium consisted almost exclusively of Sertoli cells. There was then an abrupt transition to a short tubulus rectus lined by a low cuboidal epithelium that continued into the labyrinthine chambers of the rete.

The present paper was motivated by observation in the guinea-pig of an additional segment, rich in glycogen, which seems to have escaped detection heretofore, probably because the glycogen is not preserved by methods of fixation and embedding in general use. The presence of large amounts of stored glycogen in epithelial cells at this level in the excurrent pathway is surprising in view of the fact that the rete testis fluid in other species such as rat and ram contains no glucose or fructose (Setchell \& Waites, 1971). A comparative ultrastructural analysis of the tubuli recti and rete testis in several other mammalian species, including rat, monkey and ram, revealed little or no intra-epithelial glycogen (Dym, 1972, 1974).

\section{MATERIALS AND METHODS}

Material was obtained from seven guinea-pigs. For observation of the location and extent of the rete, the testes of three animals were fixed by vascular perfusion with Helly's, Bouin's or Stieve's fluid, embedded in paraffin wax, serially sectioned for light microscopy and stained with the periodic-acidSchiff reaction and haematoxylin. The remainder of the light microscope observations were based upon $0.5-\mu \mathrm{m}$ sections of Epon/araldite-embedded testis fixed by perfusion with collidine-buffered $5 \%$ glutaraldehyde followed by immersion in a $1: 1$ mixture of $2 \%$ osmium tetroxide in water and $3 \%$ potassium ferrocyanide in water (Karnovsky, 1971).

The method of perfusion through the spermatic artery has been described in an earlier publication (Fawcett, Heidger \& Leak, 1969). Thick sections $(0.5 \mu \mathrm{m})$ and thin sections with silver to gold interference colours were cut from the same blocks with a diamond knife on a Sorvall MT-1 microtome. The thicker sections were stained with toluidine blue for light microscopy. The thin sections were supported on uncoated grids, stained with uranyl acetate and lead citrate (Venable \& Coggeshall, 1965), and examined with RCA EMU-3G or Phillips 200 electron microscopes.

\section{RESULTS}

\section{Histological observations}

In serial parasagittal paraffin wax-embedded sections, the terminal portion of the seminiferous tubules can be located with little difficulty. Their continuity with the rete testis is not easily illustrated, however, because the tubules are often sharply recurved in the junctional region, and both structures are only rarely in the same plane of section (Pl. 1, Fig. 2). The terminal segment 
of the seminiferous tubule, termed the 'intermediate region' by Perey et al. (1961), tapers down to about half the prevailing diameter in more proximal regions of the tubule and its lining epithelium comes to consist almost exclusively of Sertoli cells (Text-fig. 1A). At the junction of this segment with the tubulus rectus, the columnar epithelium of Sertoli cells suddenly gives way to a low cuboidal epithelium (Text-fig. 1 and Pl. 1, Fig. 2). The tall Sertoli cells near the junction are often inclined 'downstream' and their ends may

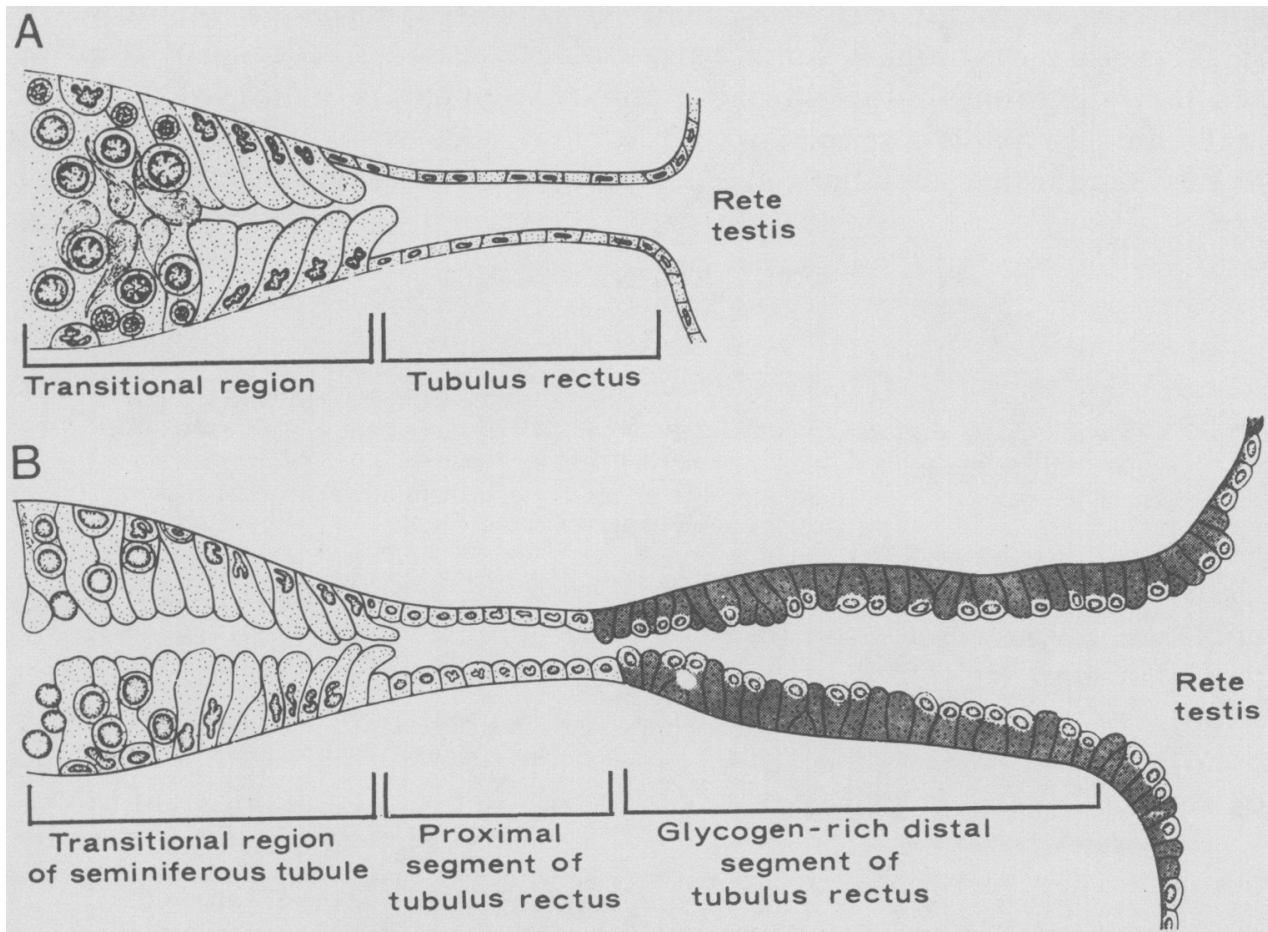

TEXT-FIG. 1. (A) Drawing of the intratesticular excretory pathway of the guinea-pig (after Perey et al., 1961; Vitali \& Aoki, 1969). (B) Drawing modified to incorporate the findings of the present study. The short initial segment of the tubulus rectus is followed by a longer tubular segment lined by glycogen-storing columnar cells. This epithelium continues into the rete where the cells become reduced in height and contain progressively less glycogen. The low cuboidal cells of the distal portions of the rete contain little or no glycogen.

project some distance into the lumen of the tubulus rectus (Pl. 1, Fig. 2). Thus, in transverse or oblique sections through this junctional region, a central mass is occasionally seen consisting of apical portions of Sertoli cells separated by a narrow cleft from a surrounding layer of low cuboidal cells.

This appearance is no doubt responsible for earlier descriptions of a 'plug'like mass of Sertoli cells. When favourably sectioned, a small central lumen is always present in the intermediate region of the seminiferous tubule (Vitale \& Aoki, 1969; Dym, 1974). The initial segment of the tubulus rectus lined by cuboidal epithelium is quite short. There is then another rather abrupt transition to a distal segment of the tubulus rectus lined by plump columnar cells each with its nucleus very near the lumen (Text-fig. 1 B and Pl. 2, Fig. 5). In routinely prepared histological sections, the cell bodies of this epithelium have a 
form which suggests that they are distended, but they appear quite clear and empty with no recognizable organelles or inclusions (Pl. 1, Figs 1 and 3). It is this segment that seems not to have attracted the attention of earlier investigators. The elements lined by this epithelium of clear cells are tubular in form and they continue for a distance that may be several times the length of the initial segment of the tubulus rectus, before opening out into the irregular chambers of the rete testis (Pl. 1, Fig. 1). It is appropriate, therefore, to consider this a distinct, distal segment of the tubulus rectus. Epithelium of the same character continues for a variable distance as the lining of the rete but then diminishes in height and gradually becomes a typical low cuboidal epithelium such as is described in the rete of other species.

When testes that have been fixed by perfusion with glutaraldehyde followed

\section{EXPLANATION OF PLATES}

\section{PLATE 1}

FIG. 1. Photomicrograph of guinea-pig testis fixed by perfusion with Stieve's solution. The confluence of the distal segment of the tubulus rectus with the rete testis is shown. Both are lined by a columnar epithelium of clear cells of empty appearance with apical nuclei. With other fixatives, these cells are found to be filled with glycogen.

Fig. 2. Photomicrograph illustrating the continuity of a seminiferous tubule with the tubulus rectus. The sharply recurved seminiferous tubule diminishes in diameter in an intermediate region where its epithelium comes to consist entirely of tall Sertoli cells. These suddenly give way to a cuboidal epithelium lining the short initial segment of the tubulus rectus. The tubuli gradually expand and the epithelium changes abruptly to clear columnar cells distended with glycogen. The glycogen-rich segment of the tubulus rectus is cut tangentially which gives a misleading impression of its size. A typical midlongitudinal section of such a tubule is seen in Fig. 1.

Fig. 3. Photomicrograph of the epithelium of the distal segment of the tubulus rectus from a paraffin wax-embedded section of guinea-pig testis fixed with Stieve's solution. The cells appear distended and the nuclei are displaced to the apex but the cell bodies appear empty even though the preparation was stained with the periodic-acid-Schiff reaction for carbohydrates.

Fig. 4. Photomicrograph of a comparable segment of tubulus rectus from a block fixed in glutaraldehyde followed by ferrocyanide-reduced osmium tetroxide and embedded in Epon-araldite. The glycogen has been preserved in most of the cells and is heavily stained.

\section{PLATE 2}

FIG. 5. Photomicrograph showing the cuboidal epithelium of the initial segment of guineapig tubulus rectus in the lower part of the figure and the abrupt transition (at arrows) to glycogen-rich columnar epithelium in the upper half of the figure. The area enclosed in the rectangle is shown in a low-power electron micrograph in Fig. 6.

Fig. 6. Electron micrograph of the area of the initial segment of the tubulus rectus indicated by the rectangle in Fig. 5. The cells of the cuboidal epithelium have nuclei of higher irregular outline and cytoplasm rich in membranous organelles. Only small amounts of glycogen are found in the cytoplasm. The particles in the lumen are glycogen that has escaped from cells in the glycogen-rich segment of the tubule during specimen preparation.

\section{PLATE 3}

Fig. 7. Photomicrograph of the glycogen-rich segment of two tubuli recti from guinea-pig testis fixed with glutaraldehyde-osmium-ferrocyanide. Most of the epithelial cells have retained their glycogen content. A few (marked by asterisks) seem to have been disrupted in preparation and their glycogen has escaped into the lumen. An area comparable to that in the box at the upper left is shown in an electron micrograph in Fig. 8.

Fig. 8. Electron micrograph of epithelium of the glycogen-rich segment showing the variable height of the cells, their dome-shaped adluminal ends occupied by a lobulated nucleus. Glycogen fills most of the cell body. It is not clear whether the variation in concentration of glycogen from cell to cell is real or an artifact of displacement or partial plasmalysis. 
PI.ATE I
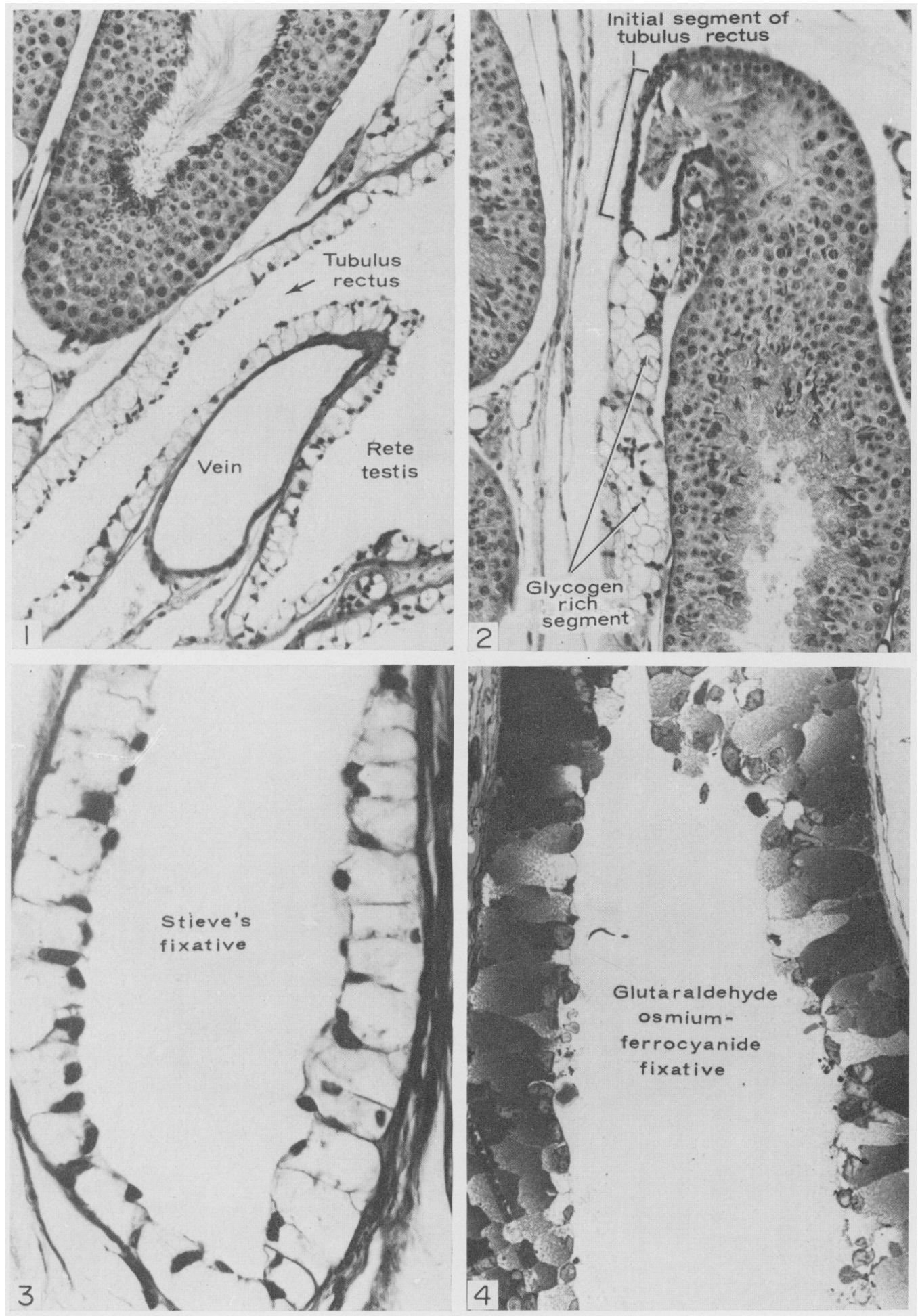

Iacing p. $+(1)+$ 


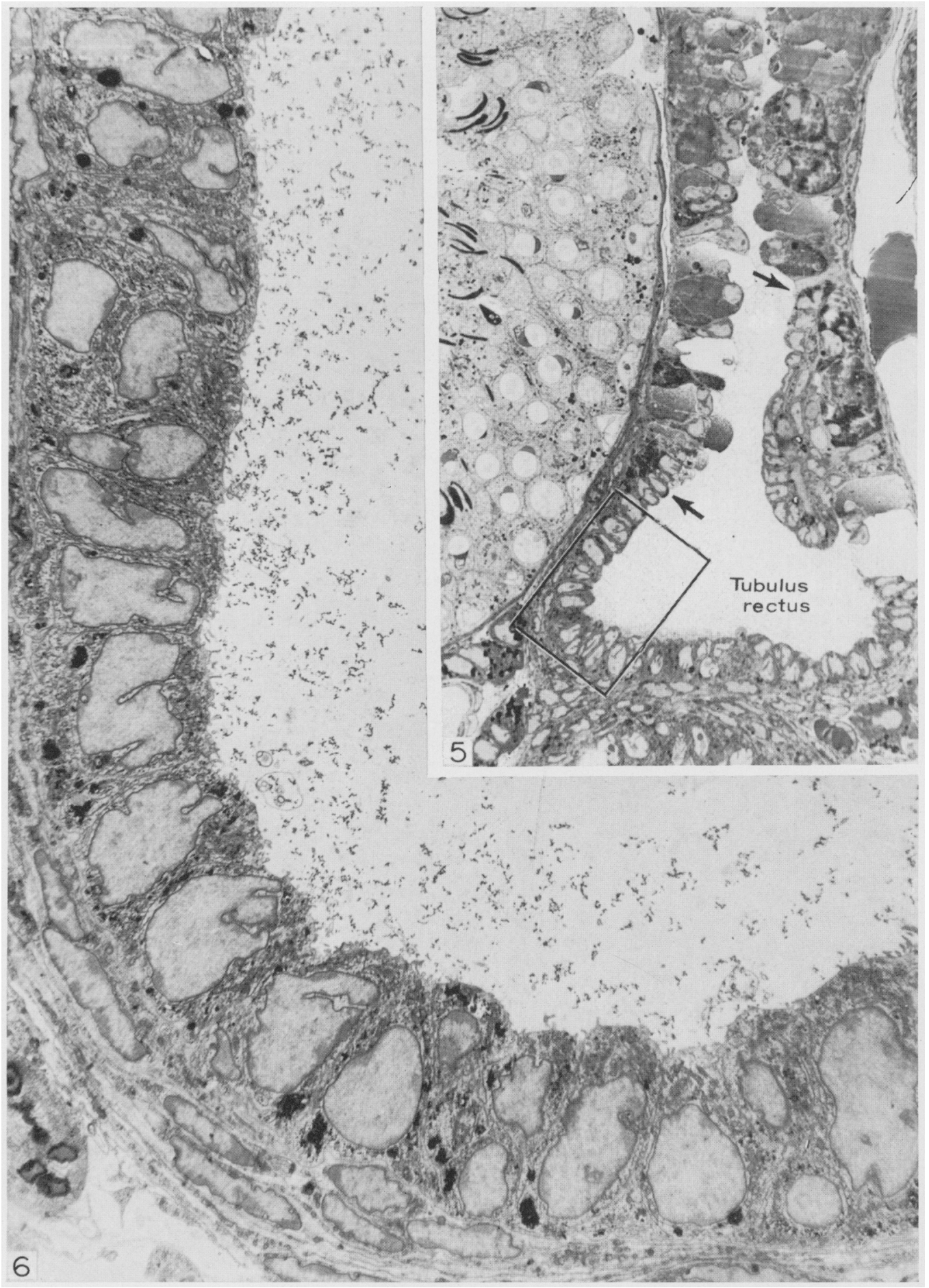


PLATE 3
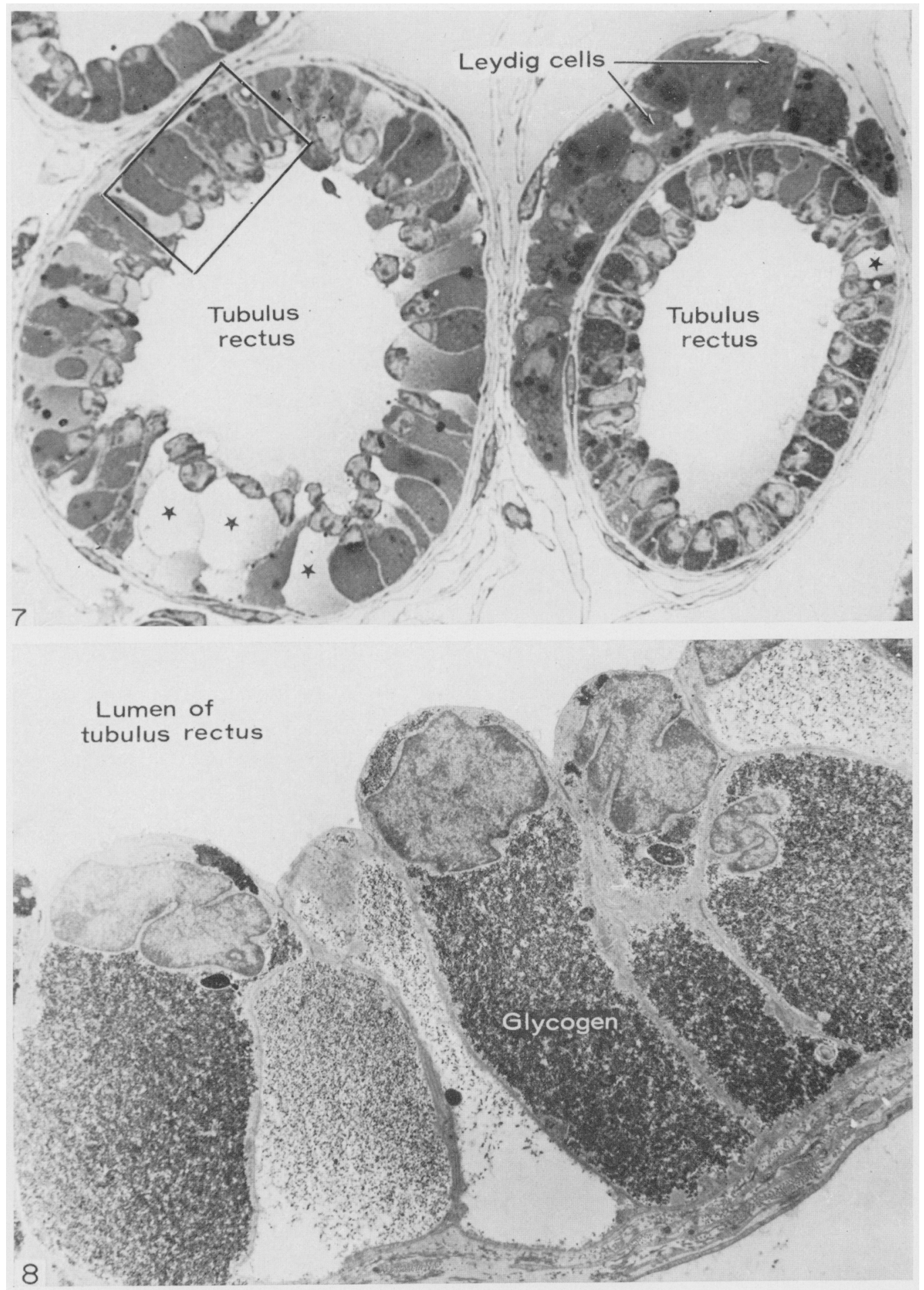


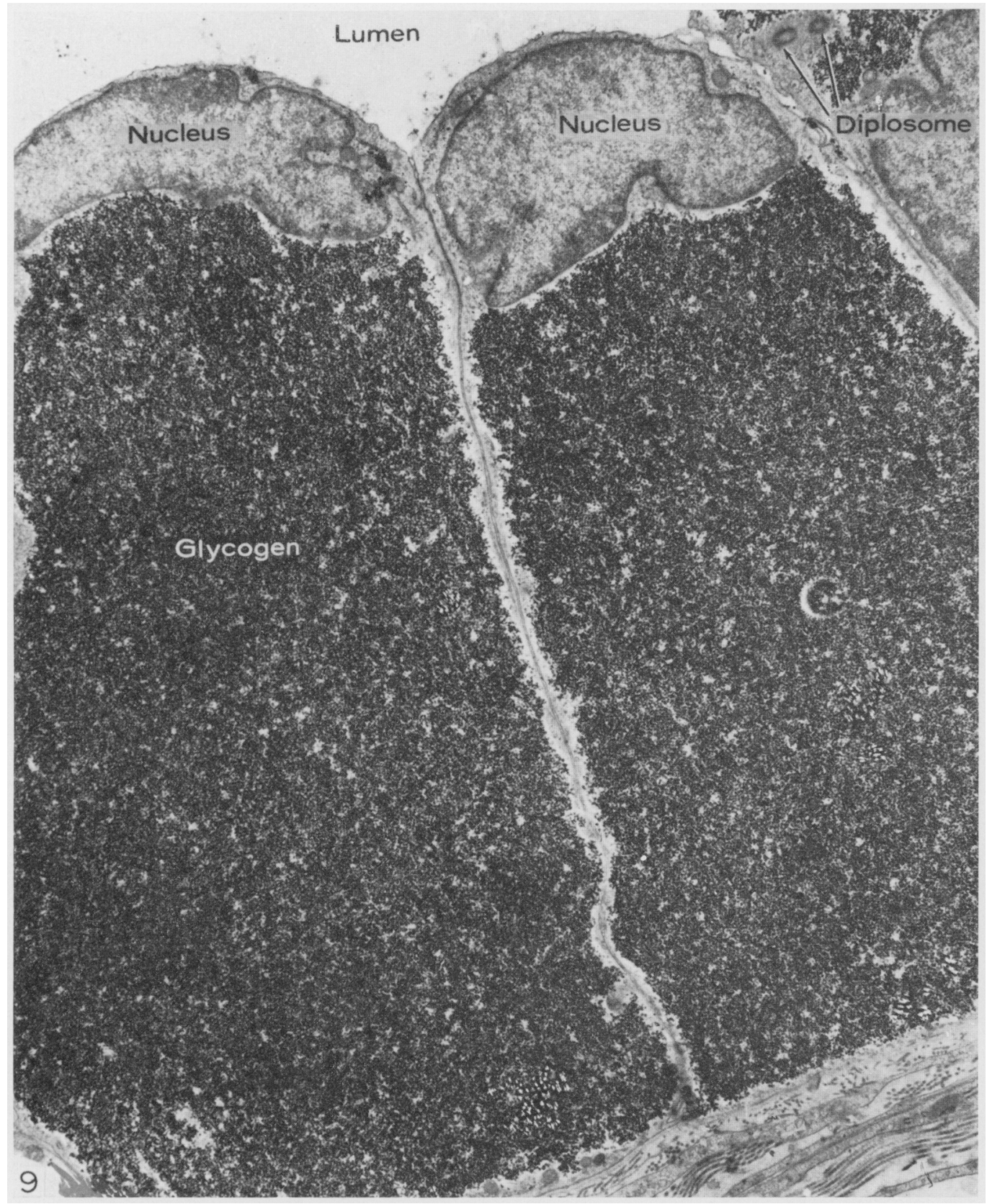




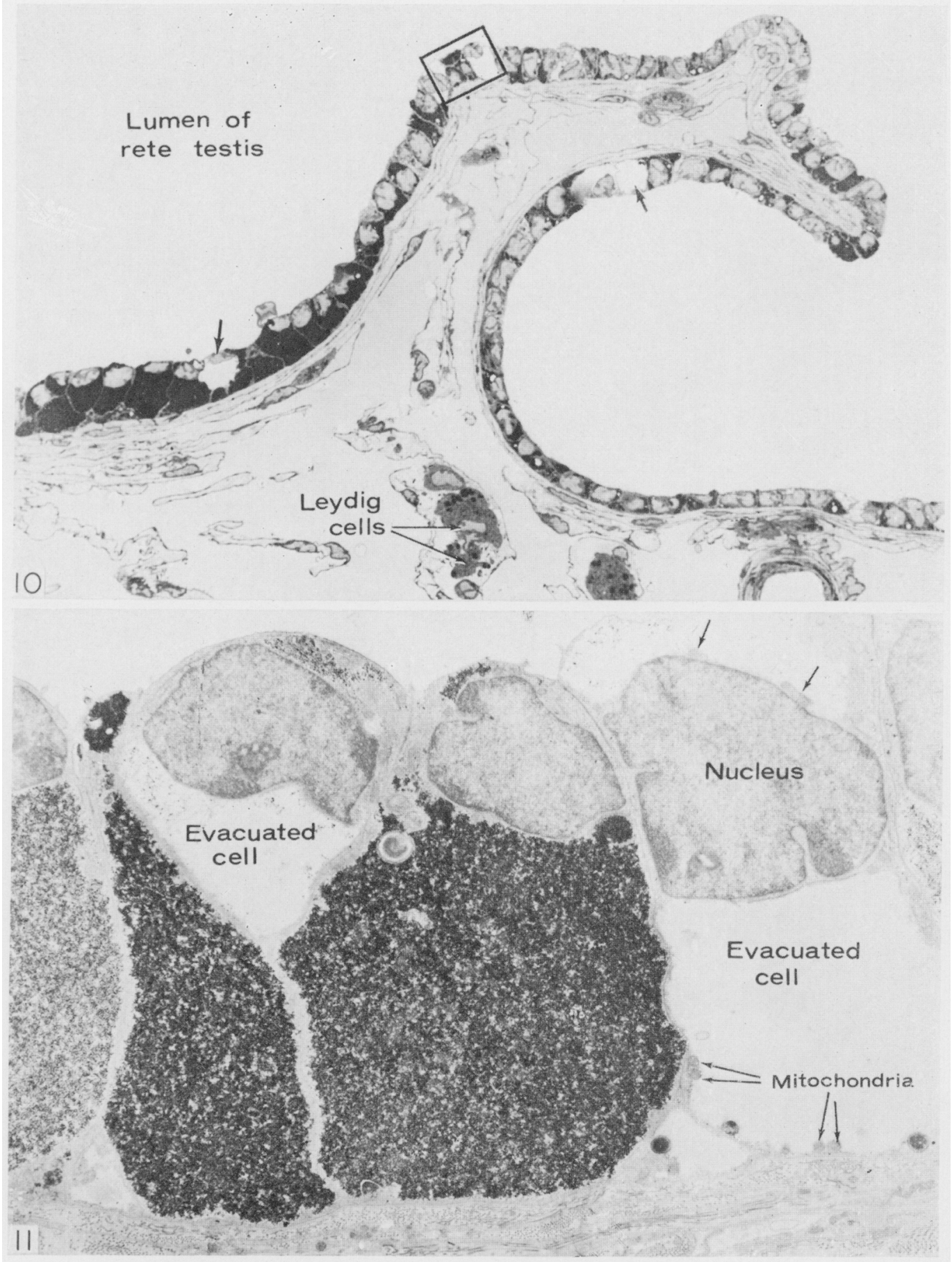


Lumen

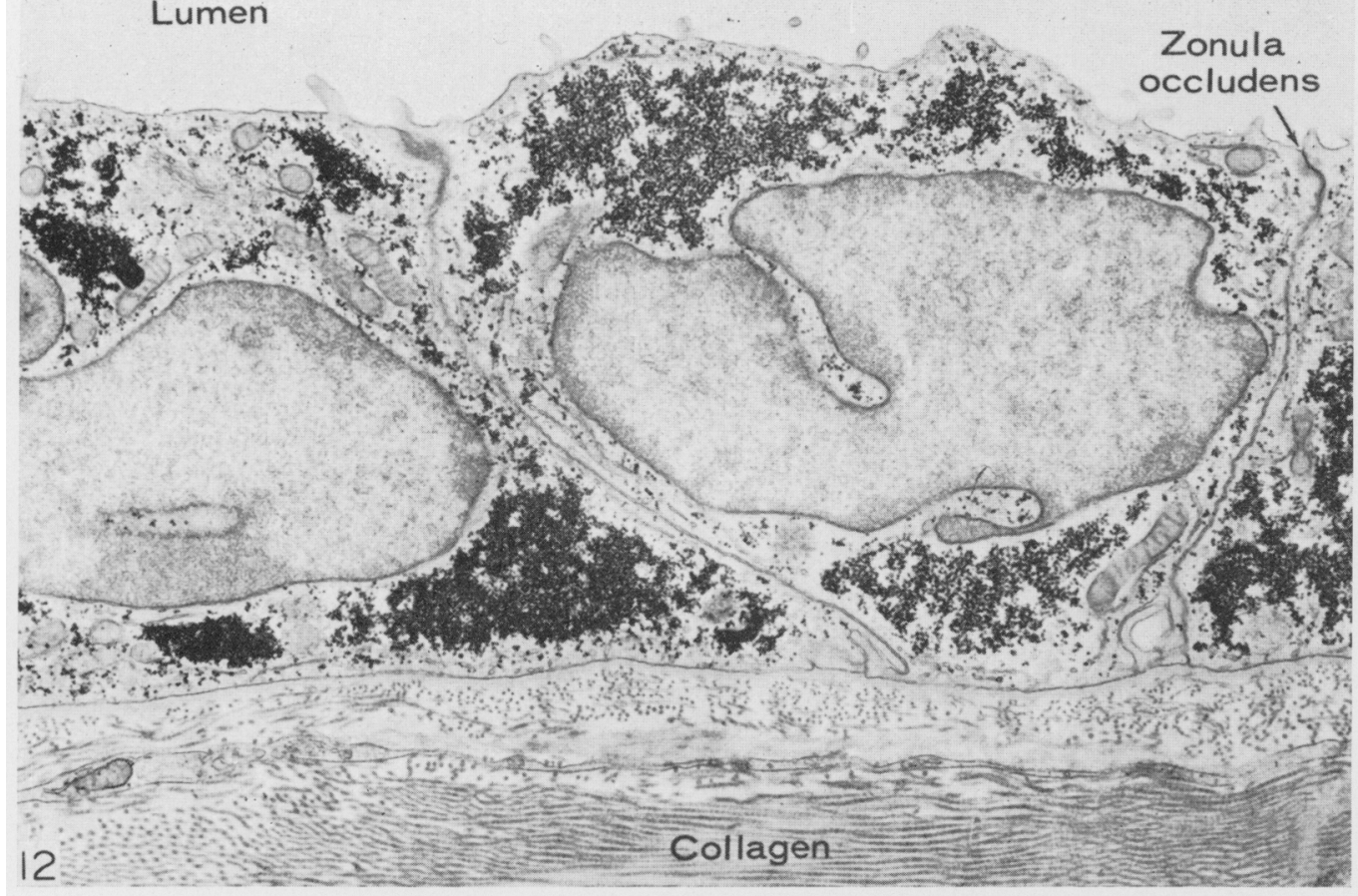

\title{
Lumen of
}

rete testis

\author{
Golgi \\ complex
}

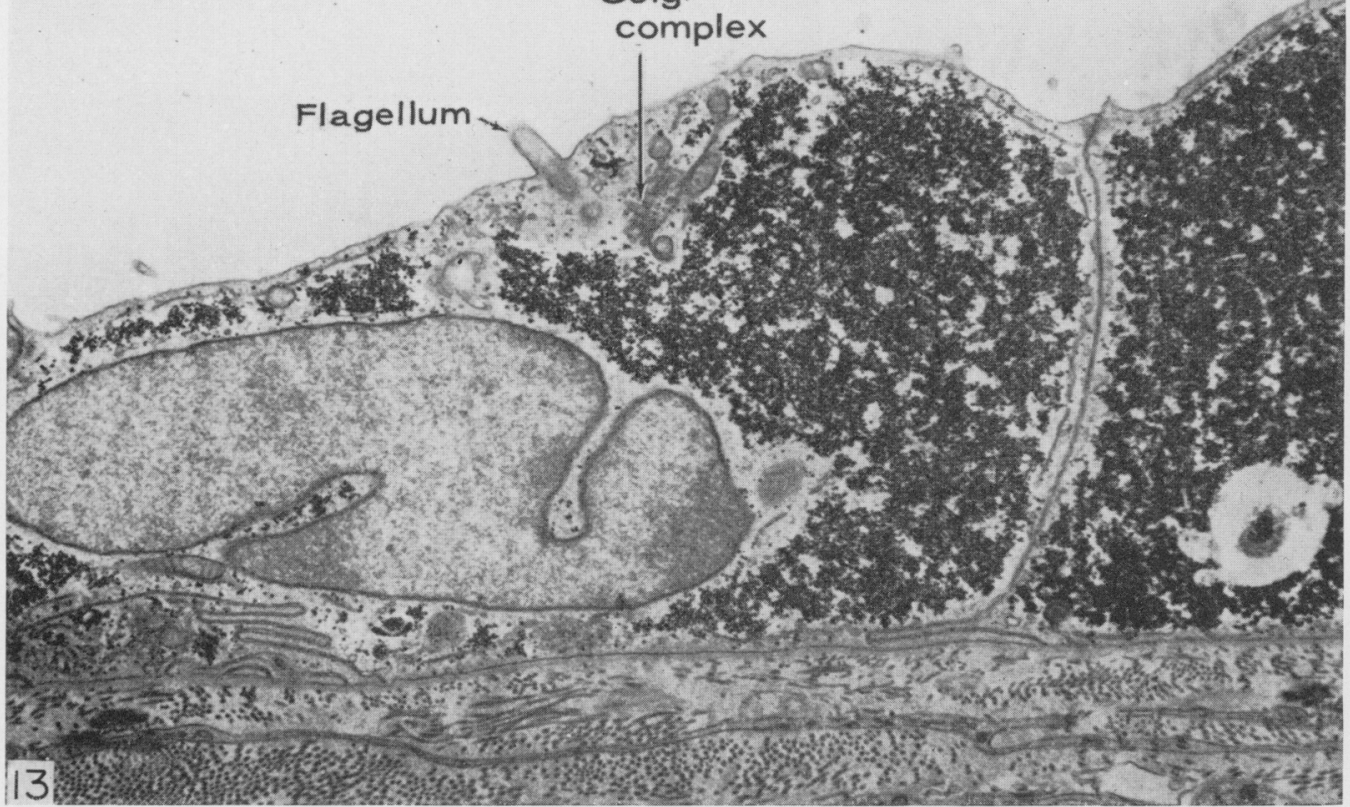

(Facing p. 405) 
by immersion in a solution of ferrocyanide-reduced osmium tetroxide are examined with the light microscope in $0.5-\mu \mathrm{m}$ plastic sections, the appearance of the epithelium in the distal segment of the tubulus rectus is entirely different. Although occasional cells appear clear and empty (Pl. 1, Fig. 4 and Pl. 3, Fig. 7), the great majority are filled with darkly stained material (compare Pl. 1, Fig. 3 with Fig. 4 and Pl. 3, Fig. 7). In some instances, this dense material has been swept across the cell during penetration of the fixative leaving one side pale and the other side very dense. This is a phenomenon familiar to histologists and histochemists in cells rich in glycogen (Deane, Nesbitt \& Hastings, 1946). Electron microscopic examination of material from the same blocks confirms the presence in these cells of a high concentration of dense particles with the dimensions, fine structure and staining properties of glycogen.

\section{Electron microscopic observations}

The cells of the cuboidal epithelium in the proximal segment of the tubulus rectus have nuclei of highly irregular outline, and cytoplasm rich in membranous organelles (Pl. 2, Fig. 6). A moderate number of glycogen particles are distributed throughout the cytoplasm but seldom aggregated in dense masses. Glycogen particles may be found in the lumen (Pl. 2, Fig. 6) but this is believed to be an artifact of specimen preparation resulting from rupture of glycogenstoring cells further along the excurrent duct system.

In electron micrographs of the epithelium in the distal segment of the tubulus rectus, the columnar cells are completely filled with dense $\beta$-particles of glycogen (Pl. 3, Fig. 8). Only a thin rim of cytoplasm is discernible around the periphery of the mass of stored glycogen. It is evident that the juxtaluminal position of the nucleus is due to its displacement by the accumulation of glycogen in the cell body. The nucleus is deeply infolded and irregular in

\section{EXPLANATION OF PLATES}

PLATE 4

FIG. 9. Electron micrograph of two glycogen-storing epithelial cells. Notice the extraordinary concentration of the $\beta$-particles of glycogen and the reduction of the cytoplasmic matrix to a thin layer immediately beneath the plasma membrane. A diplosome is frequently observed in the apical region.

PLATE 5

Fig. 10. Photomicrograph of the wall of the guinea-pig rete testis. The glycogen-rich epithelium of the distal segment of the tubuli recti continues into the lining of the rete (at left) but the height of the epithelium and the concentration of glycogen diminishes. Occasional cells (arrowed) have lost their glycogen. An area comparable to that in the box is shown at higher magnification in Fig. 11 .

FIG. 11. Electron micrograph of several epithelial cells. Some retain their full complement of glycogen, others appear to have undergone plasmalysis with an outpouring of their glycogen. Mitochondria and other organelles remain in the thin shell of cytoplasm adjacent to the cell membrane.

PLATE 6

FIGs 12 and 13. Electron micrographs of the epithelium lining the proximal part of the guinea-pig rete testis. The cells are attached by juxtaluminal zonulae occludentes, and rest upon a lamina propria of fibroblasts and bundles of thin collagen fibrils. The cells are polarized toward the lumen with a small Golgi complex located between the nucleus and the luminal surface. A diplosome is often associated with the Golgi complex and one member of the pair serves as the basal body of a single flagellum. The one shown here quickly passes out of the plane of section. 
outline with a moderate amount of chromatin distributed mainly at the periphery. A diplosome is situated at the apex of the cell (Pl. 4, Fig. 9) and a few mitochondria and a small Golgi complex are present in the thin rim of cytoplasm between the nucleus and the apical plasma membrane. The concentration of glycogen differs somewhat from cell to cell. Within the same cell, there may be one or two membrane-limited aggregations of glycogen that are more closely packed than the general store of glycogen around them.

Some cells in the epithelium are largely empty (Pl. 3, Fig. 7 and Pl. 5, Figs 10 and 11), and glycogen particles are found in the lumen of the tubules. It is believed that the cells of this epithelium are uncommonly fragile and that some are broken during specimen preparation, permitting their content of glycogen to escape into the lumen. The finding that spherical membranelimited masses of glycogen sometimes remain within a cell that otherwise appears empty is consistent with this interpretation. In such cases, the diffuse glycogen content has presumably poured out through a breach in the cell membrane leaving behind the nucleus, the peripheral rim of cytoplasm and one or two membrane-bounded masses of glycogen. These latter are also occasionally seen in the lumen.

Where the glycogen-rich epithelium continues into the labyrinthine chambers of the rete, the height of the cells decreases and they contain relatively more cytoplasm and less glycogen (Pl. 5, Fig. 10 and Pl. 6, Figs 12 and 13). Instead of a single large depôt, there may be several smaller areas of glycogen separated by glycogen-free partitions of cytoplasmic matrix. Some of the cuboidal cells of the rete have a single flagellum projecting into the lumen (Pl. 6, Fig. 13).

\section{DISGUSSION}

Considering the voluminous literature on the histology and histochemistry of the male reproductive tract, it is quite extraordinary that a glycogen-rich segment of the intratesticular portion of the duct system could have escaped detection until now. We have been unable, however, to find previous descriptions of such a segment. Indeed, Guha \& Wegmann (1966) specifically deny the presence of histochemically demonstrable glycogen in the adult guinea-pig testis though they do report the presence of active phosphorylase in the rete testis. The failure to make this observation early may be, in part, a reflection of the preoccupation of reproductive biologists with spermatogenesis, and with those parts of the duct system most accessible to experimental manipulation. It may also be attributable, in part, to the fact that the guinea-pig has been less popular than the rat as an experimental animal. The axial rete of the guinea-pig is relatively small and does not appear in all sections of a serially sectioned testis. Investigators encountering by chance the distorted, empty cells of the epithelium may have simply attributed this appearance to poor fixation and were not stimulated to investigate the content of the large central vacuoles.

It should be emphasized that secondary fixation with $1.3 \%$ osmium tetroxide buffered in s-collidine does not preserve the intra-epithelial glycogen of the guinea-pig tubuli recti and rete testis. A satisfactory explanation cannot be 
given at present either for our success in demonstrating glycogen with the osmium tetroxide-potassium ferrocyanide fixative or for the failure of other fixation procedures which preserve glycogen satisfactorily in other tissues. Karnovsky (1971) pointed out the superiority of ferrocyanide-reduced osmium over other methods for staining glycogen and carbohydrate-rich coatings of cell membranes, but was unable to define the chemical nature and staining mechanism of the complex formed by treating osmium tetroxide with ferrocyanide. DeBruijn (1973) published a more detailed study of its staining characteristics and presented abundant evidence that the granules stained were, in fact, glycogen. The focus of this last paper was also upon the properties of the complex as a stain but no claim was made for its greater effectiveness in the preservation of glycogen. Our success in demonstrating glycogen in the tubuli recti and rete depended primarily upon the fact that glycogen was retained in the cells, whereas with other fixation methods, the cells are evidently broken and their glycogen content lost in the preparation stages preceding the staining of the sections. The fragility of the glycogen-laden cells was obvious even in the present study where glycogen granules were consistently found in the lumen of the duct system. A considerable number of the lining cells were empty - apparently having broken open in preparation, discharging their content into the lumen and leaving behind only the cell membrane, a thin supporting layer of cytoplasm, and the nucleus.

The remarkable abundance of glycogen stored in these cells is deserving of comment. Accumulation of glycogen in the cell body displaces the nucleus and other organelles to a thin rim of cytoplasm at the periphery. To our knowledge, the only vertebrate cells with a comparable store of carbohydrate are those of the glycogen body of the chick shortly before hatching. This conspicuous ovoid body occupies the fossa rhomboidalis in the lumbosacral region of the spinal cord in incubating birds. Its cells were described by early histologists as 'water-clear', 'gelatinous', or 'albumin-like'. Terni (1924) first demonstrated histochemically that this strange organ stored large amounts of glycogen intracellularly. Quantitative analyses have shown that glycogen constitutes 75 to $80 \%$ of its fat-free dry weight (Watterson, 1949; Doyle \& Watterson, 1949). In electron micrographs, its cells are strikingly similar to those described here (Revel, Napolitano \& Fawcett, 1960). Since the function of this body is not known, however, the morphological similarity of its cells to those of the guinea-pig tubuli recti provides no insight into the possible physiological significance of the latter.

The amount of intracellular glycogen in this segment of the testis would seem far in excess of any conceivable requirement as an energy source for possible metabolic activities of the tubuli recti and rete testis in the elaboration or modification of the testicular fluid. In ejaculated semen of the ram and other species, alkali-resistant polysaccharide, which behaves like glycogen and yields glucose on hydrolysis, seldom exceeds $0.1 \%$ and may be as little as $0.019 \%$ (Mann, 1964). Although we have observed glycogen in the lumen of the excurrent ducts in the guinea-pig, it seems unlikely that polysaccharide would be stored in such abundance without a 'turn-over'. The reported presence of active phosphorylase in the adult guinea-pig rete testis (Guha \& 
Wegmann, 1966) would suggest that glycogenolysis does occur. Whether glycogenolysis results in release of glucose into the lumen of the testicular excurrent duct system or into the blood is not known.

In those species in which it has been possible to collect rete testis fluid, virtually no glucose or fructose (which could be converted to glycogen) has been detected (Setchell, 1970). There are, however, appreciable amounts of sorbitol and inositol and it is conceivable that the cells of the guinea-pig tubuli recti and rete testis may take these up from the testicular fluid and utilize them in glycogenesis. It has been shown that the ductuli efferentes in the hamster can actively absorb sodium glucose and water (Montorzi \& Labiano, 1970) and the intratesticular portions of the duct system may also be able to take up inositol, sorbitol and glycogenic amino acids.

It is generally assumed that spermatozoa are immotile until exposed to oxygen or to a carbohydrate substrate and it is thought that they are not ordinarily exposed to appreciable amounts of carbohydrate substrate until ejaculation when they are mixed with fructose-rich secretions of the accessory glands. If technically feasible, it would be of interest to collect and analyse rete testis fluid from the guinea-pig to see if it is exceptional in this regard. It would also be of interest to determine whether glycogen accumulation in the tubuli recti and rete testis is androgen-dependent.

\section{ACKNOWLEDGMENTS}

Supported by Research Grant HD-02344 from the Institute of Child Health and Human Development, National Institutes of Health and by Research Grant No. M-73.26 from the Population Council, Inc.

\section{REFERENCES}

BENoIT, M. J. (1926) Recherches anatomiques, cytologiques et histologiques sur les voies excreteces du testiculi chez les mammifères. Archs Anat. microsc. 5, 175.

Deane, H. W., Nesbitt, F. B. \& Hastings, A. B. (1946) Improved fixation for histological demonstration of glycogen and comparison with chemical determinations in liver. Proc. Soc. exp. Biol. Med. 63, 401.

DeBruijn, W. C. (1973) Glycogen, its chemistry and morphological appearance in the electron microscope. 7. Ultrastruct. Res. 42, 29.

Doyle, W. L. \& Watterson, R. L. (1949) The accumulation of glycogen in the 'glycogen body' of the nerve cord of the developing chick. 7. Morph. 85, 391.

Dyм, M. (1972) The mammalian rete testis. Anat. Rec. 172, 304, Abstr.

Dym, M. (1973) The fine structure of the monkey (Macaca) Sertoli cell and its role in maintaining the blood-testis barrier. Anat. Rec. 175, 639.

DYM, M. (1974) The fine structure of monkey Sertoli cells in the transitional zone at the junction of the seminiferous tubules with the tubuli recti. Am. F. Anat. (in press).

Dym, M. \& FawceTt, D. W. (1970) The blood-testis barrier in the rat and the physiological compartmentation of the seminiferous epithelium. Biol. Reprod. 3, 308.

Fawcetr, D. W. (1974) Sertoli cell, germ cell interaction. In Proc. Serono Symposium on Male Fertility and Sterility (in press).

Fawcett, D. W., Heidger, P. M. \& Leax, L. V. (1969) Lymph vascular system of the interstitial tissue of the testis as revealed by electron microscopy. J. Reprod. Fert. 19, 109.

Guha, S. \& Wegmann, R. (1966) Activité phosphorylasique dans la testicule et dans l'épididyme de cobaye avant et après la maturation sexuelle. Annls Histochim. 11, 213.

Karnovsky, M. J. (1971) Use of ferrocyanide-reduced osmium tetroxide in electron microscopy. 7. Cell Biol. Abstract 284. 
Ladman, A. J. \& Young, W. G. (1958) An electron microscopic study of the ductuli efferentes and rete testis of the guinea pig. F. biophys. biochem. Cytol. 4, 219 .

LeEson, T. S. (1962) Electron microscopy of the rete testis of the rat. Anat. Rec. 144, 57.

Mann, T. (1964) The Biochemistry of Semen and of the Male Reproductive Tract. Methuen, London.

Montorzi, N. M. \& Labrano, S. A. (1970) Uptake of water, sodium, and glucose by the ductuli efferentes of the hamster. Acta physiol. latinoam. 20, 135.

Perey, B., Clemmont, Y. \& Leblond, C. P. (1961) The wave of the seminiferous epithelium in the rat. Am. F. Anat. 108, 47.

Revel, J. P., Napolitano, L. \& Fawcett, D. W. (1960) Identification of glycogen in electron micrographs of thin tissue sections. 7. biophys. biochem. Cytol. 8, 575 .

Roosen-Runge, E. C. (1961) The rete testis in the albino rat: its structure, development, and morphological significance. Acta anat. 45, 1.

Setchell, B. P. (1970) Testicular blood supply, lymphatic drainage, and secretion of fluid. In The Testis, Vol. 1, p. 101. Eds. A. D. Johnson, W. R. Gomes and N. L. VanDemark. Academic Press, New York.

Setchell, B. P. \& Waites, G. M. H. (1971) The exocrine secretion of the testis and spermatogenesis. 7. Reprod. Fert., Suppl. 13, 15.

Terni, T. (1924) Ricerchi sulla cosidetta sostanza gelatinosa (corpo glicogenico) del midollo lombosacrale digli uccelli. Archo ital. Anat. Embriol. 21, 55.

Tuck, R. R., Waites, G. M. H., Young, J. A. \& Setchell, B. P. (1970) Composition of fluid secreted by the seminiferous tubules of the rat collected by catheterization and micropuncture techniques. 7. Reprod. Fert. 21, 367.

Venable, J. H. \& Coggeshall, R. (1965) A simplified lead stain for use in electron microscopy. $\boldsymbol{J}$. Cell Biol. 25, 407.

Vitale, R. \& AoKi, A. (1969) Fine structure of the intratesticular excretory pathway in the guinea pig. Z. Anat. EntwGesch. 129, 135.

Voglmayr, J. K., Waites, G. M. H. \& Setchell, B. P. (1966) Studies on spermatozoa and fluid collected directly from the testis of the conscious ram. Nature, Lond. 210, 861.

Watterson, R. L. (1949) Development of the glycogen body of the chick spinal cord. I. Normal morphogenesis, vasculogenesis and anatomical relationships. F. Morph. 85, 337. 